Check for updates

Hurley Group, London

clare.gerada@nhs.net

Cite this as: BMJ 2020;371:m3843

http://dx.doi.org/10.1136/bmj.m3843

Published: 06 October 2020

WOUNDED HEALER

\title{
Clare Gerada: Bracing for the second wave
}

\section{Clare Gerada GP partner}

We're gearing up for the inevitable second wave of this pandemic, this time over the long, dark days of winter. Over the summer, as the sun shone brightly and restaurants and pubs opened, we could have been forgiven for thinking that we were heading back to some sort of normality. But of course, we knew that the lull could not last long and that the virus was still around.

It's hard not to be despondent that all our collective efforts of handwashing, physical distancing, face masks, quarantine, and now curfews seem to be in vain. However, we must remind ourselves that we're in a far better position than during those grim days in April when death rates were at their peak.

We now understand the virus better-who is at greatest risk, what treatments work, and which ones don't-and we hopefully even have a vaccine on the horizon. But still, among the increasing numbers of doctors I see in my service for sick doctors, there is anticipatory dread, intense anxiety, and a constant feeling of unease, as though something bad is about to happen. The "bad" is that they will be asked again to risk their lives, see their colleagues die from covid-19, make immense sacrifices in their personal lives to serve their patients, and generally be called on to show superhuman abilities.

However, doctors don't wear magic white coats that protect them from fatigue, grief, and fear. Pandemics place health professionals at increased risk of mental illness, uncomfortable psychological emotions, and moral injury. They must contend with other additional burdens. During the first wave I ran a group for health practitioner leaders, from medicine, nursing, paramedicine, and management. Not only did they work very hard (up to 16 hours a day, every day for weeks on end) but they were often blamed for factors out of their control, such as inadequate personal protective equipment (PPE), insufficient intensive care beds, and implementing ever changing protocols and guidelines. They had to deal with protests from staff as they were blamed for failings in the system-and from patients as waiting lists grew longer.

Clinicians are still exhausted and, despite the brief respite, are not fully recovered from the frenetic pace of the first wave and the mid-summer surge of non-covid-related activity. The clapping may have stopped, and the rainbows faded, but our compassion for care workers must continue. There is now a moral imperative to ensure that the mental health of NHS staff is a top priority; that we put in place the systems and structures that we know work (peer support groups, good team working, shorter shifts, flexible working arrangements, easy access to psychological supports); and that, as we enter the next stage, we remember that doctors are human too.

Clare Gerada is the editor of Beneath the White Coat: Doctors, Their Minds and Mental Health, which will be launched in a Zoom webinar on Thursday 8 October 2020 at 6 pm. To register, visit https://us02web.zoom.us/webinar/register/WN_yncpxYvNTNqYuOWOiitaJQ. All proceeds will be donated to Doctors in Distress (registered charity).

Competing interests: See https://www.bmj.com/about-bmi/freelance-contributors.

Provenance and peer review: Commissioned; not externally peer reviewed.

This article is made freely available for use in accordance with BMJ's website terms and conditions for the duration of the covid-19 pandemic or until otherwise determined by BMJ. You may use, download and print the article for any lawful, non-commercial purpose (including text and data mining) provided that all copyright notices and trade marks are retained. 